Original Article

\title{
PROTEASE INHIBITOR FROM WHITE CRANBERRY BEANS (PHASEOLUS VULGARIS): ISOLATION, PURIFICATION AND CHARACTERIZATION
}

\author{
ASHWINI PUNTAMBEKAR ${ }^{1}$, MANJUSHA DAKE2* \\ ${ }^{1}$ Lecturer, Protein Biochemistry Laboratory, Dr. D. Y. Patil Biotechnology and Bioinformatics Institute, Dr. D. Y. Patil Vidyapeeth, Pune, \\ Maharashtra, India, ${ }^{2}$ Assistant professor, Protein Biochemistry Laboratory, Dr. D. Y. Patil Biotechnology and Bioinformatics Institute, Dr. \\ D. Y. Patil Vidyapeeth, Pune, Maharashtra, India \\ Email: manjusha.dake@dpu.edu.in
}

Received: 03 Jun 2017 Revised and Accepted: 22 Jul 2017

\begin{abstract}
Objective: The main objective of the study was isolation, purification and characterization of protein protease inhibitor from the seeds of Phaseolus vulgaris and analysis of its antimicrobial potential.

Methods: The protease inhibitor was extracted by homogenizing seeds of Phaseolus vulgaris in $0.1 \mathrm{M}$ phosphate buffer (pH-7.0). The crude extract of the inhibitor was purified by using ammonium sulphate precipitation followed by DEAE Cellulose ion exchange chromatography. The protease inhibitor was characterized to determine its optimum $\mathrm{pH}$ and $\mathrm{pH}$ stability, optimum temperature and temperature stability, stability in the presence of chemical modifiers, thermal stabilizers, metal ions, detergents, oxidising and reducing agents. The antimicrobial potential of the inhibitor against
\end{abstract} various bacterial species was confirmed using agar well diffusion method.

Results: The extracted protease inhibitor was purified to homogeneity with a 1.4 fold increase in the specific activity and $56 \%$ purification yield. Inhibitor was optimally active at $\mathrm{pH} 7.0$ and a temperature of $50{ }^{\circ} \mathrm{C}$ as well as showed considerable stability over pH ranging from 4.0 11.0 and up to a temperature of $70{ }^{\circ} \mathrm{C}$ for $4 \mathrm{~h}$ duration. The inhibitor was substantially active and stable in the presence of surfactants $1 \%(\mathrm{v} / \mathrm{v})$ Tween $20,4 \%(\mathrm{v} / \mathrm{v})$ of oxidizing agents such as dimethyl sulphoxide (DMSO) and hydrogen peroxide $\left(\mathrm{H}_{2} \mathrm{O}_{2}\right), 0.8 \%$ (v/v) of reducing agents $\beta$ mercaptoethanol and Sodium thioglycolate. Metal ions $\mathrm{Mg}^{++}, \mathrm{Ca}^{++}$and $\mathrm{Zn}^{++}$enhanced the activity of inhibitor while $\mathrm{CaCl}_{2}$, glycine and glycerol promoted thermal stability of the inhibitor. Chemical modification of amino acids at the active site by diethyl pyrocarbonate (DEPC) and phenyl methyl sulphonyl fluoride (PMSF) led to decrease in the inhibitory activity. The stoichiometry of trysin-protease inhibitor interaction was 1:2 while $216 \mu \mathrm{g}$ of the inhibitor effected $50 \%$ inhibition. The inhibitor displayed antimicrobial activity against Aeromonas hydrophilla, Citrobacter freundii and Acinetobacter baumanii.

Conclusion: The experimental results confirmed the anti proteolytic action of protease inhibitor extracted from P. vulgaris as well as its promising antimicrobial properties. Thus isolated protease inhibitor has significant industrial and therapeutic potential.

Keywords: Protease, White beans, Inhibitor, Activity, Extracellular

(C) 2017 The Authors. Published by Innovare Academic Sciences Pvt Ltd. This is an open access article under the CC BY license (http://creativecommons.org/licenses/by/4.0/) DOI: http://dx.doi.org/10.22159/ijpps.2017v9i9.20472

\section{INTRODUCTION}

Proteolytic enzymes belong to hydrolase category catalyze cleavage of specific peptide bonds in certain proteins. These are ubiquitously distributed among plants, animals and diverse microbial flora [1-3].

Extracellular proteases hydrolyze macromolecular proteins to smaller peptide and amino acids that are readily absorbed by the cell whereas intracellular proteases are involved in the regulation of cellular metabolism. Proteases are indispensible and play important role in many physiological processes such as blood clotting, host defence, wound healing, inflammation, cell growth and migration, tumor growth and metastasis, zymogen activation and hormone processing pathways [4]. Uncontrolled proteolytic activity triggers unfavourable metabolic events causing proteolytic cleavage and disruption in the homeostatic balance. Control of protease through binding of macromolecular protease inhibitors is one of the strategies for their effective regulation. Some proteases are the key virulent factors in many pathogenic bacteria, parasites and viruses. Inhibition of such proteases through selective action of protease inhibitors can provide an effective strategy to control pathogenesis. Protease inhibitors are a diverse group of proteins showing biochemical activity with a major role to combat proteins of pests and pathogens $[5,6]$. Most of the protease inhibitors cause inhibition of metalloproteinases, cysteine proteinases and aspartic proteinases. Serine protease inhibitors modulating the activity of large number of serine and cysteine proteases form superfamily class of protease inhibitors [7]. Protease inhibitors are widely distributed in plants, animals and microorganisms as well as archea
[8]. Protease inhibitors act as defensive proteins and have great demand in medicine and biotechnology. They can be applied as therapeutics against emphysema, arthritis, and pancreatitis. They are also involved in anti-nutritional interactions against insect gut proteases. Microbial food spoilage is the worldwide problem causing loss of $25 \%$ of food products [9]. Food preservation by increasing the shelf life can be feasible by the action of natural protease inhibitors originating from a plant source that could possibly inhibit extracellular and intracellular proteolytic enzymes during food storage [10].

Most of the protease inhibitors are small molecular weight molecules with molecular mass ranging from 5-25 KDa. Compact nature and higher content of disulfide bridges can contribute to the thermal stability of protease inhibitors [11].

Plants produce certain protease inhibitors as defensive proteins that develop immunity as a result of insect attack. The signaling pathways initiated in plants promote resistance towards insect attack [12]. Protease inhibitors are valuable tools in biochemical and biomedical studies that hinder the action of certain proteolytic enzymes indispensable for cancer and AIDS like viruses and can be formulated as effective drugs for treating such life threatening diseases [13].

White cranberry variety $P$. vulgaris is not studied as a source of protease inhibitor. Thereby the work in this manuscript deals with the extraction, isolation, and purification of a trypsin inhibitor from white cranberry beans, biochemical characterization of the inhibitor and evaluation of its antimicrobial potential. 


\section{MATERIALS AND METHODS}

\section{Materials}

Diethylaminoethyl (DEAE) cellulose, phenyl methyl sulphonyl fluoride (PMSF), diethyl pyrocarbonate (DEPC) [Sigma Aldrich, Bangalore, India], bovine serum albumin (BSA), casein, tris base, sodium chloride, glycine, glycerol, $\beta$-mercaptoethanol, sodium hydroxide, monobasic sodium phosphate, dibasic sodium phosphate, magnesium sulphate $\left(\mathrm{MgSO}_{4}\right)$, calcium chloride $\left(\mathrm{CaCl}_{2}\right)$, zinc sulphate $\left(\mathrm{ZnSO}_{4}\right)$, sodium chloride $(\mathrm{NaCl})$, copper sulphate $\left(\mathrm{CuSO}_{4}\right)$, dimethyl sulfoxide (DMSO), hydrogen peroxide $\left(\mathrm{H}_{2} \mathrm{O}_{2}\right)$ and sodium acetate (HiMedia Laboratories, Ghatkopar West, Mumbai, Maharashtra), and other chemicals used were of analytical grade.

\section{Extraction and recovery of protease inhibitor}

A buffer extract was prepared in a by homogenizing $25 \mathrm{~g}$ of seeds of Phaseolus vulgaris in $100 \mathrm{ml}$ of $0.1 \mathrm{M}$ phosphate buffer with $\mathrm{pH} 7.0$ in an electrical blender. The homogenate was further mixed thoroughly by incubating the contents at room temperature in a rotary shaker for $30 \mathrm{~min}$ at $150 \mathrm{rpm}$. The homogenate was filtered through cheese cloth and centrifuged at $10,000 \mathrm{rpm}$ for $15 \mathrm{~min}$ at 4 ${ }^{\circ} \mathrm{C}$ and the clear supernatant obtained and was assayed for protease inhibitor activity and protein content.

\section{Protease inhibitor assay}

The activity of protease inhibitor against protease was assayed according to the procedure described by Kunitz with slight modifications [14]. One $\mathrm{ml}$ aliquot of trypsin (SRL, India) $0.5 \mathrm{mg} / \mathrm{ml}$ equal to $500 \mathrm{U} / \mathrm{mg}$ ) prepared in phosphate buffer $(0.1 \mathrm{M}, \mathrm{pH} 7.0)$ was pre incubated with $1 \mathrm{ml}$ of suitably diluted protease inhibitor at $37^{\circ} \mathrm{C}$ for $15 \mathrm{~min}$, which was followed by further addition of $2.5 \mathrm{ml} 1$ $\%$ casein (Hi Media, India), prepared in $0.1 \mathrm{M}$ phosphate buffer. The reaction mixture was incubated at $37^{\circ} \mathrm{C}$ for $30 \mathrm{~min}$ and the reaction was terminated by addition of $2.5 \mathrm{ml}$ of $110 \mathrm{mmol}$ ) trichloroacetic acid (TCA) solution. The residual caseinolytic activity of trypsin measured in the presence of inhibitor was used as a measure of inhibitory activity. Assay for Trypsin carried out by following the same assay procedure without the addition of inhibitor used as a control. The protease inhibitor activity was expressed in terms percent inhibition of Trypsin activity.

\section{Purification of inhibitor}

Ammonium sulphate precipitation of the prepared sample was done according to the method described by Englard and Seifter [15]. Ammonium sulphate was slowly added at $80 \%(\mathrm{w} / \mathrm{v})$ saturation to the crude inhibitor extract under ice cold conditions along with the gentle stirring. The resulting solution was kept at $\pm 4{ }^{\circ} \mathrm{C}$ for overnight precipitation. The precipitate was collected by centrifugation at $10,000 \mathrm{rpm}$ for $15 \mathrm{~min}$ at $\pm 4{ }^{\circ} \mathrm{C}$, dissolved in the extraction buffer and dialyzed against the same buffer. The dialyzed extract was used as a source of inhibitor for Trypsin. The protein content was measured by following the method of Lowry et al. [16].

The active protease inhibitor fraction was further purified by Ion exchange chromatography, using DEAE cellulose as the anion exchanger [17]. Partially purified inhibitor (13.5 mg) was loaded on the top of the column. Unbound protein sample was collected by washing the column with same equilibration buffer. Fractions of 5 $\mathrm{ml}$ were collected by maintaining the flow rate of $25 \mathrm{ml} / \mathrm{h}$. The bound protein fraction was further eluted by applying the linear gradient of $0.5 \mathrm{M} \mathrm{NaCl}$. Fractions with protease inhibitory activity were pooled and used for further analysis.

\section{Characterization of protease inhibitor}

\section{Optimal pH for protease inhibitor activity and stability}

Optimum $\mathrm{pH}$ for the maximal activity of protease inhibitor was determined by performing the inhibitor assay at different $\mathrm{pH}$ ranging from $2.0-12.0$. The substrate $1 \%$ casein was prepared in the respective buffer for each $\mathrm{pH}$. The buffer systems used were, glycine-HCl Buffer ( $\mathrm{pH}$ 2.0-3.5), citrate buffer ( $\mathrm{pH}$ 4.0-6.0), phosphate buffer ( $\mathrm{pH}$ 6.0-8.0), tris- $\mathrm{HCl}$ buffer ( $\mathrm{pH}$ 8.0-9.0), carbonate bicarbonate buffer (pH 9.5-10.5), boric acid/potassium chloride/sodium hydroxide $(\mathrm{pH}$ 11.0), disodium hydrogen phosphate/sodium hydroxide ( $\mathrm{pH}$ 12.0). Protease inhibitor activity was calculated using standard assay procedure. The residual activity of protease indicates the effect of $\mathrm{pH}$ on a protease inhibitor. The stability of protease inhibitor was analysed by pre incubating the inhibitor in different buffers with $\mathrm{pH}$ ranging from 2.0-12.0 for $24 \mathrm{~h}$, at $\pm 4{ }^{\circ} \mathrm{C}$. Inhibitor sample was analyzed for protease inhibitor activity by performing the anti-proteolytic assay at $37^{\circ} \mathrm{C}$ for $30 \mathrm{~min}$. $\mathrm{pH}$ stability of the protease inhibitor was evaluated in terms of percent inhibition of trypsin.

\section{Optimal temperature for protease inhibitor activity}

The optimum temperature for the maximal activity of protease inhibitor was determined by assaying the inhibitor activity at different temperatures ranging from $10-90^{\circ} \mathrm{C}$ for $30 \mathrm{~min}$ using the reaction mixture containing $2.5 \mathrm{ml}$ casein, $1 \mathrm{ml}$ trypsin and $1 \mathrm{ml}$ of protease inhibitor. Optimal temperature of inhibitor was determined based upon the extent of inhibition of protease activity.

Temperature stability of purified protease inhibitor was evaluated by incubating $1.5 \mathrm{ml}$ of inhibitor at different temperatures ranging from $30{ }^{\circ} \mathrm{C}-90{ }^{\circ} \mathrm{C}$. The sample was drawn at different time intervals as $30 \mathrm{~min}, 2 \mathrm{~h}, 4 \mathrm{~h}$, and $6 \mathrm{~h}$ and assessed for inhibitor activity.

Effect of various surfactants, oxidizing agents and reducing agents on protease inhibitor activity

The protease inhibitor was incubated in the presence of non-ionic surfactants such as Triton X-100, Tween-80 and Tween-20 at $1 \%$ $(\mathrm{w} / \mathrm{v})$ concentration for $30 \mathrm{~min}$. The inhibitor was dialyzed against $0.01 \mathrm{M}$ phosphate buffer $(0.1 \mathrm{M}, \mathrm{pH} 7.0)$ and estimated for the residual inhibitory activity. Effect of oxidizing agents on the activity of protease inhibitor was evaluated by incubating the inhibitor with $1,2,3,4$ and $5 \%(\mathrm{v} / \mathrm{v})$ of $\mathrm{H}_{2} \mathrm{O}_{2}$ and DMSO for 30 min while for reducing agents the inhibitor was incubated in the presence of 0.2 , $0.4,0.6,0.8$ and $1 \%(\mathrm{v} / \mathrm{v}) \quad \beta$-mercaptoethanol and sodium thioglycolate for $30 \mathrm{~min}$. The residual inhibitory activity was analyzed using caseinolytic assay.

\section{Effect of various metal ions on protease inhibitor activity}

Effect of various metal ions on the activity of protease inhibitor was studied by using sodium chloride, calcium chloride, magnesium sulphate, cupric sulphate which contribute to metal ions $\mathrm{Na}^{+}, \mathrm{Ca}^{++}$, $\mathrm{Mg}^{++}$, and $\mathrm{Cu}^{++}$respectively. The inhibitor was added to $10 \mathrm{mmol}$ concentration of metal ions and incubated further at $37^{\circ} \mathrm{C}$ for 30 $\mathrm{min}$. The protease inhibitor activity was measured using caseinolytic assay.

\section{Effect of stabilizers on thermal stability of protease inhibitor}

The effect of stabilizers on the thermal stability of protease inhibitor was evaluated by incubating the inhibitor in the presence of thermal stabilizers like glycine $(1 \mathrm{M}), \mathrm{CaCl}_{2}(10 \mathrm{mmol})$, glycerol $(10 \%)$, urea $(10 \mathrm{mmol})$, sucrose $(1 \%)$ at $50{ }^{\circ} \mathrm{C}$ and $70{ }^{\circ} \mathrm{C}$ for $3 \mathrm{~h}$. At the end of incubation, the inhibitor was processed by regular assay procedure involving incubation along with trypsin and casein at $37^{\circ} \mathrm{C}$ for 30 min to calculate residual inhibitor activity.

\section{Chemical modifications of amino acids in protease inhibitor}

To study the biochemical role of amino acids present at the active site of inhibitor on its inhibitory activity, chemical modification of these amino acids was carried out using PMSF and DEPC. $2 \mathrm{ml}$ of the purified inhibitor $(2.7 \mathrm{mg} / \mathrm{ml})$ was incubated with $5 \mathrm{mmol}, 10 \mathrm{mmol}$, $15 \mathrm{mmol}, 20 \mathrm{mmol}$ and $25 \mathrm{mmol}$ of chemical modifier (DEPC and PMSF) for $30 \mathrm{~min}$. The inhibitor was dialyzed against $0.1 \mathrm{M}$ phosphate buffer (pH 7.0) and the residual protease inhibitor activity was calculated.

\section{Stoichiometry of protease-protease inhibitor interaction}

$1 \mathrm{mg} / \mathrm{ml}$ of trypsin solution prepared by using $0.1 \mathrm{M} 100 \mu \mathrm{l}$ of phosphate buffer was preincubated with different amounts of purified protease inhibitor from 54 to $432 \mu \mathrm{g}$ at $37{ }^{\circ} \mathrm{C}$ for $60 \mathrm{~min}$. The residual activity of trypsin was determined. The concentration of purified protease inhibitor required for complete inactivation of trypsin and IC-50 value were calculated. 


\section{Assay of antimicrobial activity using agar well diffusion method}

The microbial strains Aeromonas hydrophila (MCC-2052), Citrobacter freundii (MCC-2078), Acinetobacter baumannii (MCC2076) were collected from Microbial Culture Collection, National Centre for Cell Science, Pune. Antibacterial assay was carried out using the agar well diffusion method [18] as modified by Olurinola [19] using 0.5 McFarland standards.

Inoculum was prepared by growing microbial cultures of (Aeromonas hydrophila (MCC-2052), Citrobacter freundii (MCC2078), Acetinobacter baumannii (MCC-2076) at $35^{\circ} \mathrm{C}$. The turbidity of the actively growing broth culture was adjusted with sterile saline to obtain turbidity optically comparable to that of the 0.5 McFarland standards. Muller hinton agar plates were prepared by pouring 20 $\mathrm{ml}$ of molten muller hinton agar and allowed to solidify. After the agar was solidified, $100 \mu \mathrm{l}$ of McFarland adjusted culture was over layed on to the solidified agar medium.

Plates were allowed to leave for about $15 \mathrm{~min}$. Wells of $10 \mathrm{~mm}$ diameter were made in seeded agar plates using a sterile cork borer. Protease inhibitor samples were loaded along with positive control as streptomycin $(10 \mathrm{mg} / \mathrm{ml})$ and sterile distilled water as a negative control into the wells without causing overflow. Samples were allowed to diffuse and plates were incubated at $37{ }^{\circ} \mathrm{C}$ for $24 \mathrm{~h}$. Diameter of the zones of complete inhibition was measured in $\mathrm{mm}$ and recorded.

\section{RESULTS AND DISCUSSION}

Isolation of protease inhibitor from seeds of Phaseolus vulgaris

The crude extract of inhibitor from Phaseolus vulgaris prepared in phosphate buffer $(0.1 \mathrm{M}, \mathrm{pH} 7.0)$ isolated exhibited $46 \%$ inhibition for trypsin. The protease inhibitor purified by salt precipitation using $70 \%$ saturation with ammonium sulphate exhibited enhanced inhibitory activity against trypsin (59\%) compared to the crude preparation of extract.

\section{Purification of the protease inhibitor}

Ion exchange column chromatography of Phaseolus vulgaris on DEAE cellulose

Fig. 1 indicates elution profile of protease inhibitor purified by using DEAE cellulose ion exchange column chromatography. A single major protein peak with maximum inhibitory activity was eluted using step gradient of $0.5 \mathrm{M} \mathrm{NaCl}$ in phosphate buffer ( $\mathrm{pH}$ 7). Thus inhibitor was separated and purified from other non inhibitor proteins.

The data for yield and purification fold of protease inhibitor is presented in table 1 . The fold of purification of protease inhibitor observed for ammonium sulphate precipitation and ion exchange chromatography were 1.1 and 2 respectively showing successive increase in specific inhibitor activity from 22 to $33 \mathrm{U} / \mathrm{mg}$ protein.

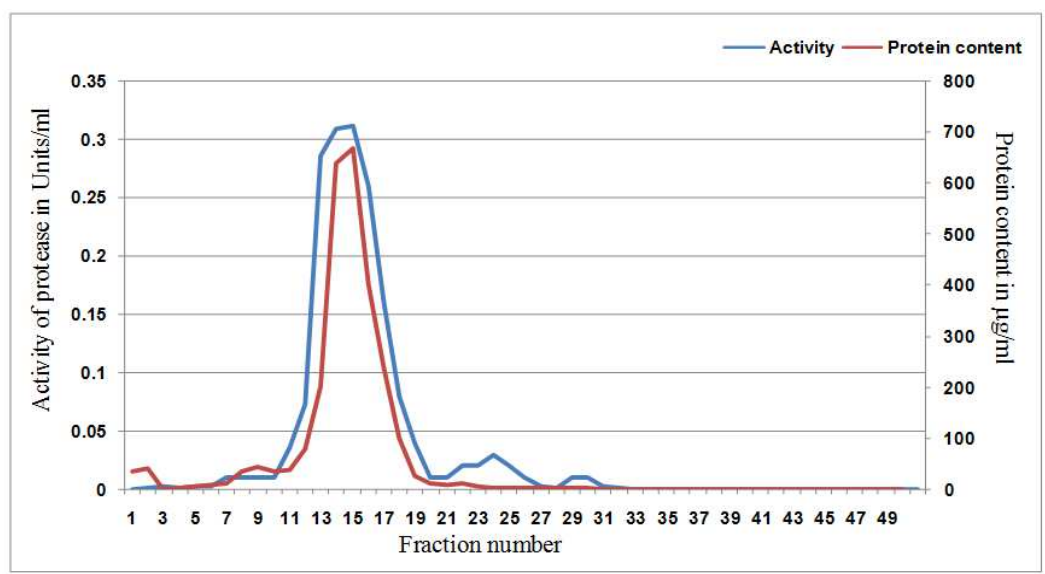

Fig. 1: Elution profile of protease inhibitor of $P$. vulgaris from DEAE cellulose column by ion exchange chromatography

Table 1: Summary of purification of protease inhibitor isolated from $P$. vulgaris seeds

\begin{tabular}{lllllll}
\hline Sample & $\begin{array}{l}\text { Volume } \\
(\mathbf{m l})\end{array}$ & $\begin{array}{l}\text { Total protein } \\
\text { (mg) }\end{array}$ & $\begin{array}{l}\text { Protease Inhibitor } \\
\text { activity (U/ml) }\end{array}$ & $\begin{array}{l}\text { Specific inhibitor } \\
\text { activity (U/mg) }\end{array}$ & $\begin{array}{l}\text { Yield activity } \\
\text { (\%) }\end{array}$ & $\begin{array}{l}\text { Fold } \\
\text { Purification }\end{array}$ \\
\hline $\begin{array}{l}\text { Crude extract } \\
\text { (NH4)2S04 Fraction }\end{array}$ & 100 & 437 & 7000 & 16 & 100 & 1 \\
$\begin{array}{l}\text { (80\%) } \\
\begin{array}{l}\text { Ion Exchange } \\
\text { Fraction }\end{array}\end{array}$ & 128 & 2800 & 22 & 40 & 1.1375 \\
\hline
\end{tabular}

The inhibitor was purified with an increase in the purification fold of 2.06 and specific activity of $33 \mathrm{U} / \mathrm{mg}$

\section{Effect of $\mathrm{pH}$ on the activity and stability of protease inhibitor}

The inhibitor was found to be active over a wide range of $\mathrm{pH}$ from 4.0 to 10.0 with maximal activity at $\mathrm{pH} 7.0$ (80\% inhibition). The decrease in inhibitory activity under highly acidic and alkaline conditions with $\mathrm{pH}$ 2.0-4.0 and 10.0-12.0 indicating denaturation of protease inhibitor. Extremes of acidic $\mathrm{pH}$ alter the structure of the inhibitor making them unable to bind with the enzyme. Some of the inhibitors from the Kunitz family are very sensitive to acidic $\mathrm{pH}$ and stable in the alkaline $\mathrm{pH}$ range [20].

The inhibitor displayed stability over a wide range of $\mathrm{pH}$ from 4.011.0 and retained the maximal inhibitory activity of $91 \%$ at $\mathrm{pH} 7.0$.
Sharp decline in inhibitor activity was denoted under extremes of acidic ( $\mathrm{pH} 2.0)$ and alkaline ( $\mathrm{pH} 12.0)$ conditions resulting $8 \%$ and $10 \%$ inhibition respectively.

The maximal inhibitory activity of $67 \%$ was shown for the inhibitor isolated from Moringa olifera leaves at $\mathrm{pH} 10.0$ [21]. Thus $\mathrm{pH}$ affects the activity, structural stability and solubility of protease inhibitor.

Effect of temperature on the activity and stability of protease inhibitor

The inhibitor remained active up to $60{ }^{\circ} \mathrm{C}$ with the maximal inhibitory activity of $93 \%$ observed at $50{ }^{\circ} \mathrm{C}$. The decline in protease 
inhibitory activity was noted at a temperature above $50{ }^{\circ} \mathrm{C}$ while inhibitor was totally inactive at $90^{\circ} \mathrm{C}$ due to thermal denaturation. Most of the cysteine protease inhibitors originating from plant source remained optimally active up to $50^{\circ} \mathrm{C}$. Incubation at higher temperature elevates kinetic energy exerting thermal influence to disrupt bonds essential for the activity of cysteine protease inhibitor [22].

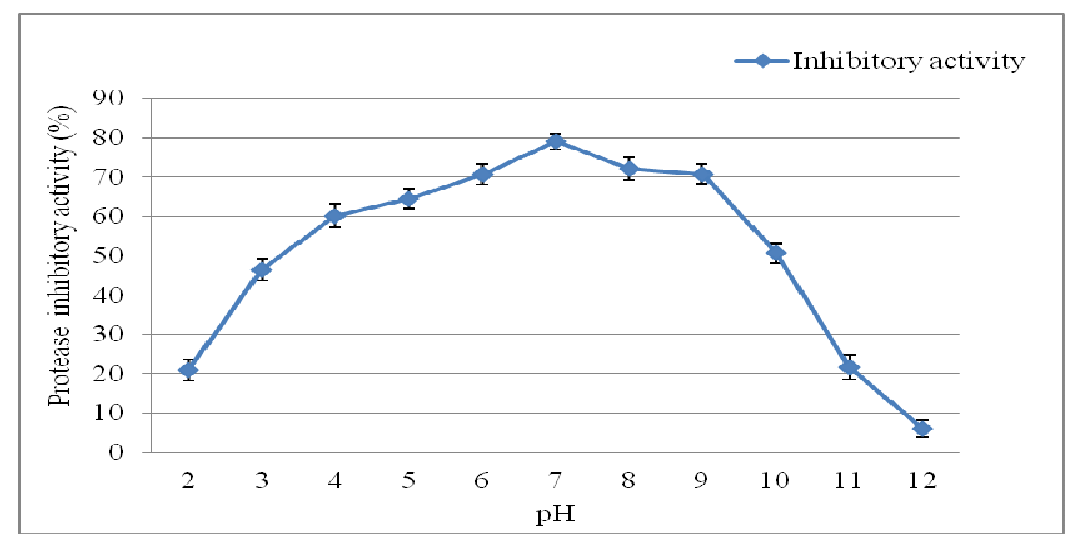

Fig. 2: Activity of protease inhibitor at different $\mathrm{pH}$, the assay of protease inhibitor was carried out using different buffer systems of $\mathrm{pH}$ 212 at $37^{\circ} \mathrm{C}$. The number of experiments, $n=3$, the data was given in mean $\pm S D$

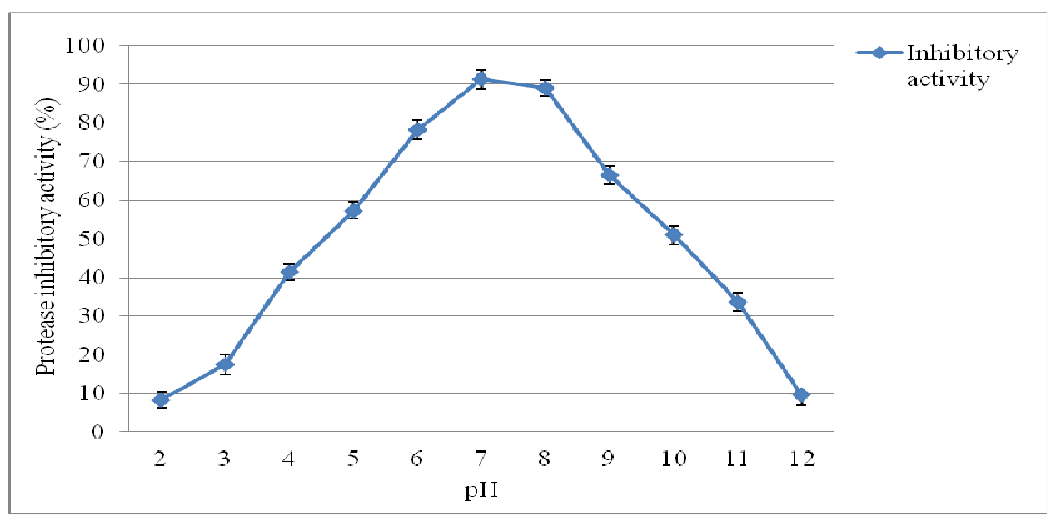

Fig. 3: Stability of protease inhibitor at different $\mathrm{pH}$. The inhibitor incubated at different $\mathrm{pH} 2-12$ for $24 \mathrm{~h}$ and assessed for the residual inhibitor activity at $37^{\circ} \mathrm{C}$ with a $\mathrm{pH}$ 7. Values are presented as mean $\pm \mathrm{SD}$ of triplicates

Preincubation of protease inhibitor with trypsin at $50{ }^{\circ} \mathrm{C}$ from 30 min to $4 \mathrm{~h}$ displayed heat stability with 92 to $96 \%$ inhibition. Inhibitor also remained stable at $70{ }^{\circ} \mathrm{C}$ for $4 \mathrm{~h}$ showing $88 \%$ inhibition. The inhibitor was found to be stable for $2 \mathrm{~h}$ at $50{ }^{\circ} \mathrm{C}$ and $70{ }^{\circ} \mathrm{C}$ exhibiting $93 \%$ and $61 \%$ inhibition respectively. The inhibitor showed half life of $4 \mathrm{~h}$ at $70^{\circ} \mathrm{C}$. The inhibitor lost its anti proteolytic activity at $90^{\circ} \mathrm{C}$ after $30 \mathrm{~min}$. Protease inhibitor isolated from actinomycetes enhanced the stability of protease at $50^{\circ} \mathrm{C}$ up to $1 \mathrm{~h}$ [23]. Most of the plant protease inhibitors of Kunitz family are active at temperatures up to $50^{\circ} \mathrm{C}$ [24-25].

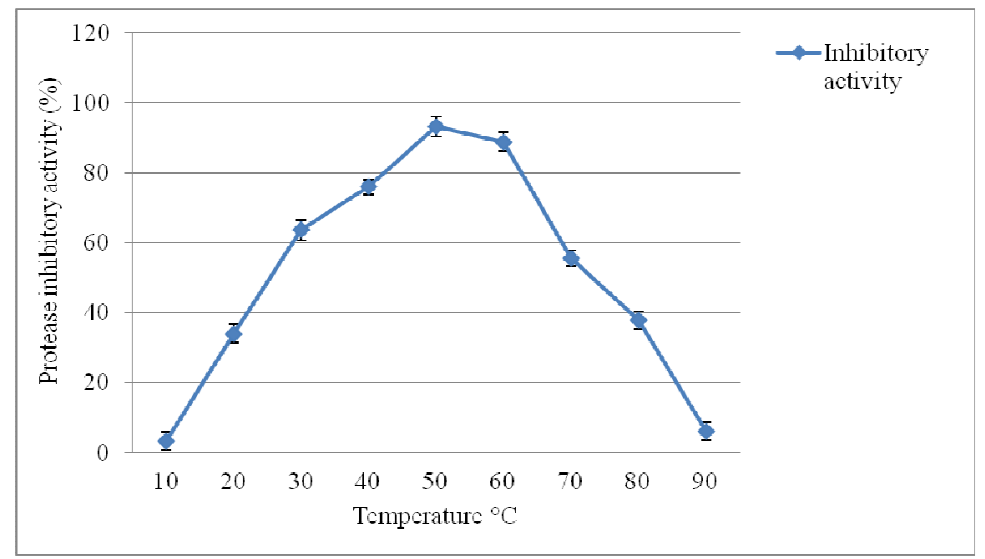

Fig. 4: Effect of temperature on protease inhibitor activity. The inhibitor assay was carried out at different temperatures ranging from 10 ${ }^{\circ} \mathrm{C}-90{ }^{\circ} \mathrm{C}$ and the residual inhibitor activity was evaluated. The data represents values as the mean of three independent experiments 


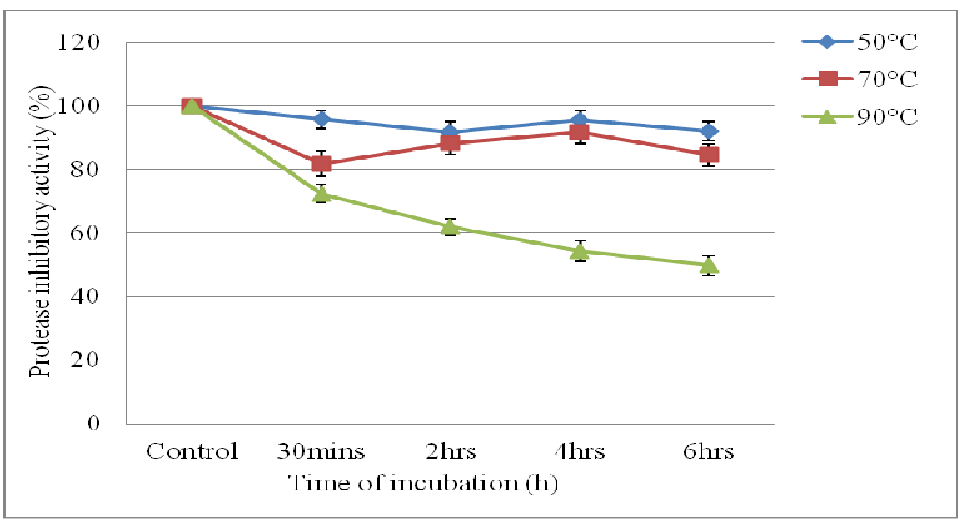

Fig. 5: Stability studies of protease inhibitor at various temperatures. The inhibitor incubated at different temperatures as $50{ }^{\circ} \mathrm{C}, 7^{\circ} \mathrm{C}$ and $90{ }^{\circ} \mathrm{C}$ for different time intervals $30 \mathrm{~min}, 2 \mathrm{~h}, 4 \mathrm{~h}$ and $6 \mathrm{~h}$, the stability was expressed in percentage of residual activity. Values are presented as mean \pm SD of triplicates

\section{Effects of surfactants on protease inhibitor activity}

All non-ionic surfactants exhibited a negative effect on the protease inhibitor activity. In the presence of Tween 20 and Tritox-X-100, the protease inhibitor activity reduced to $85 \%$ and $51 \%$ respectively (when compared to the activity of control). The inhibitory activity considered as $100 \%$ in the absence of surfactant. Preincubation with Tween 80 could inactivate the inhibitor with $90 \%$ loss in inhibitor activity. Thus the inhibitor exhibited greater stability and activity in the presence of Tween 20 with $40 \%$ loss in inhibitory activity.

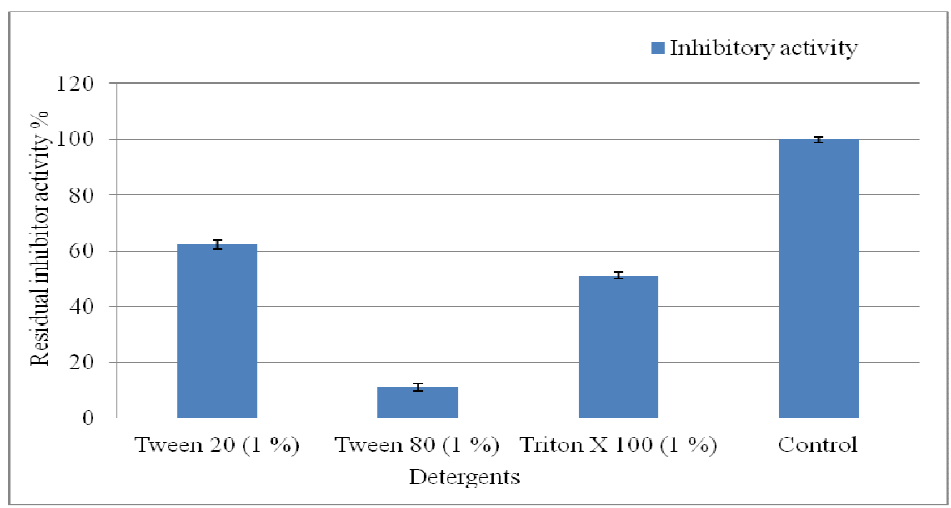

Fig. 6: Effect of surfactants on protease inhibitor activity, the residual activity of protease inhibitor was measured followed by incubation with different surfactants for $30 \mathrm{~min}$. The data were given in mean $\pm S D$

\section{Effect of oxidizing and reducing agents}

The activity of protease inhibitor decreased with corresponding increase in the concentration of oxidizing agents. The inhibitor was found to show significant stability at $1 \%$ and $4 \%$ DMSO with as $90 \%$ and $53 \%$ inhibitory activity. The inhibitor activity noted in the presence of $1 \%$ and $4 \% \mathrm{H}_{2} \mathrm{O}_{2}$ was $89 \%$ and $26 \%$ respectively. A significant decrease in the inhibitory activity to 12 $\%$ and $14 \%$ was noted at $5 \%$ concentration of DMSO and $\mathrm{H}_{2} \mathrm{O}_{2}$ respectively.

Reducing agents were observed to enhance the activity of protease inhibitor. The inhibitory activity was increased from $43 \%$ to $93 \%$ along with a corresponding increase in the concentration of $\beta$ mercaptoethanol from $0.2 \%$ to $1 \%$ respectively. In the same way, at $0.2 \%$ and $1 \%$ concentrations of sodium thioglycolate as an oxidizing agent, resulting inhibition was $22 \%$ and $95 \%$ respectively.

Oxidation of the inhibitor at key catalytic amino acid residues as methionine resulting loss of the human alpha-1-proteinase inhibitor activity [26].

\section{Effect of various metal ions on protease inhibitor activity}

Protease inhibitory activity analyzed in the presence of monovalent and divalent metal ions by incubating the inhibitor in the presence of $10 \mathrm{mmol}$ concentration of metal ions. Inhibitory activity in the absence of metal ions considered as $100 \%$ and taken as a control.
$\mathrm{MgSO}_{4}$ and $\mathrm{ZnSO}_{4}$ which provided divalent metal ions $\mathrm{Mg}^{++}$and $\mathrm{Zn}^{++}$ enhanced residual protease inhibitory activity only up to a marginal level. Divalent metal ions maintain the structural integrity of cysteine protease inhibitor by preserving their secondary and tertiary structure [27]. $\mathrm{Cu}^{++}$and $\mathrm{Na}^{+}$were noted to reduce the inhibitor activity to $93 \%$ and $10 \%$ respectively. These metal ions may interfere by binding with charged amino acid residues located within the active site region of inhibitor thereby decreasing its efficiency for binding with the enzyme.

\section{Effect of stabilizers on thermal stability of protease inhibitor}

Thermal stability of protease inhibitor was analyzed in the presence of additives as glycine, $\mathrm{CaCl}_{2}$, urea, glycerol and sucrose at $50{ }^{\circ} \mathrm{C}$ and $70{ }^{\circ} \mathrm{C}$. Inhibitor activity in absence of stabilizer was taken as a control. Protease inhibitor showed thermal stability and inhibitory activity in the presence all the stabilizers except sucrose. At $50{ }^{\circ} \mathrm{C}$ maximum stability was promoted by $\mathrm{CaCl}_{2}$ (92\% inhibition) followed by glycerol (87 \%), glycine (70\%) and sucrose (64\%). At an elevated temperature of $70{ }^{\circ} \mathrm{C}, \mathrm{CaCl}_{2}(92 \%)$ stabilized the inhibitor substantially. Glycine (22\%) and glycerol (39\%) displayed moderate thermal stability while urea conferred $20 \%$ protection to protease inhibitor at $70^{\circ} \mathrm{C}$. But sucrose at $70{ }^{\circ} \mathrm{C}$ did not support the thermal stability of inhibitor resulting thermal inactivation. Parallel results were obtained for Moringa leaf inhibitor [28]. Amino acids, salts and polyols have been reported to enhance thermal stability of proteins [29]. 


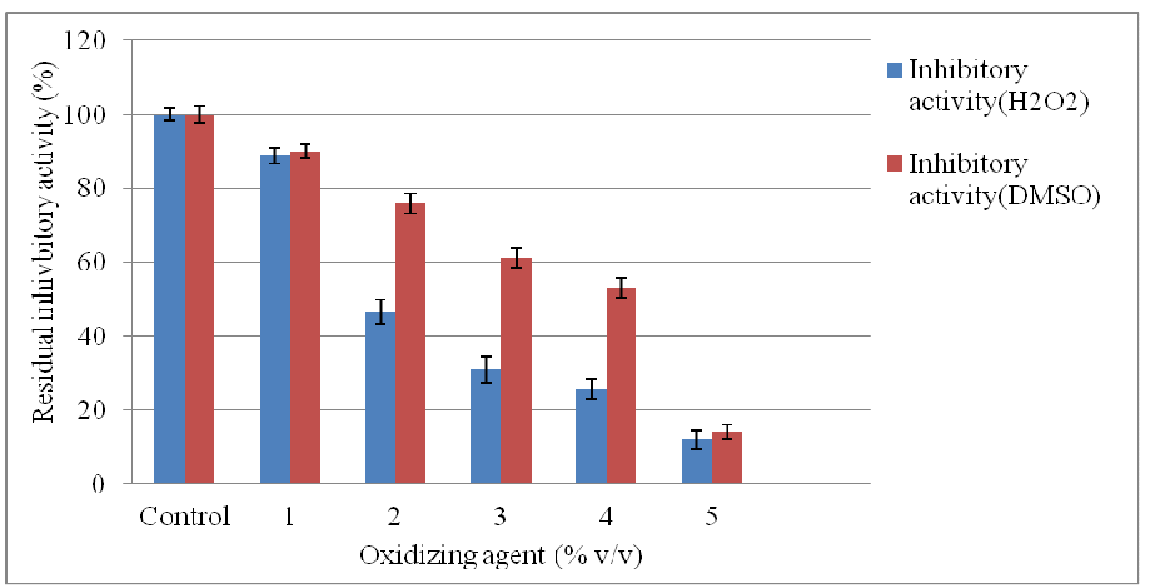

Fig. 7: Effect of oxidizing agents on protease inhibitor activity, Values are given as mean \pm SD of three sets of observations

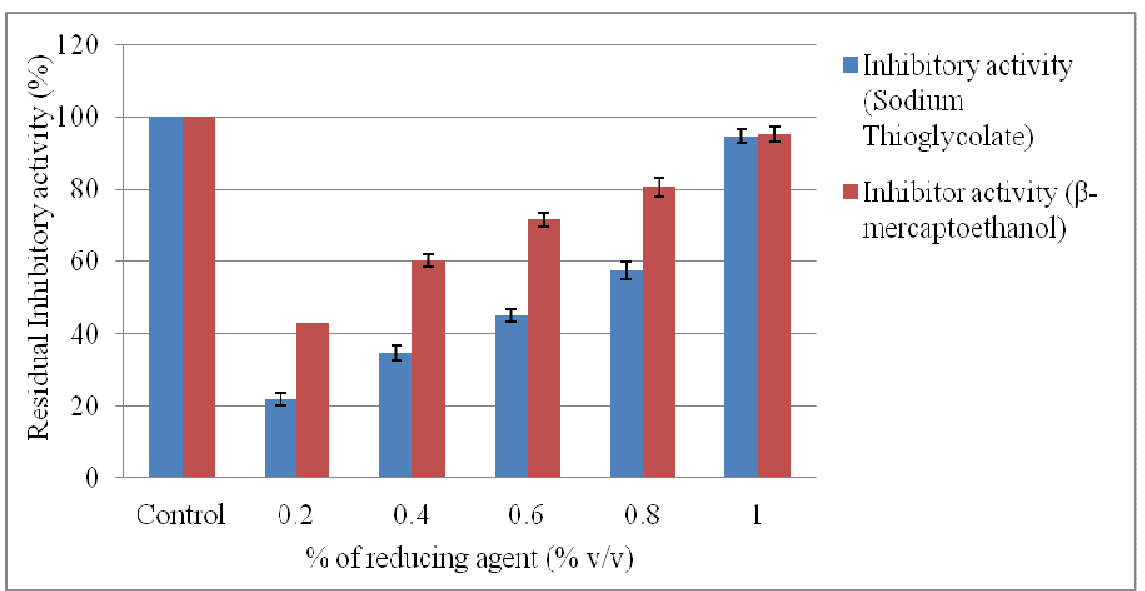

Fig. 8: Effect of reducing agents on protease inhibitor activity, Values are presented as mean $\pm S D$ of three sets of observations

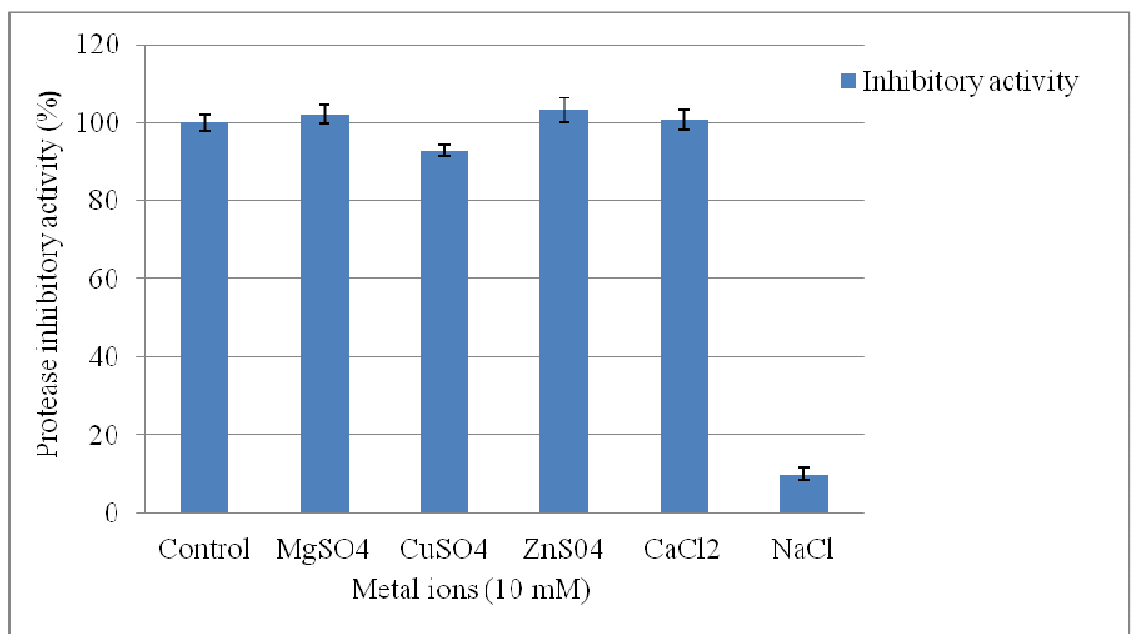

Fig. 9: Effect of metal ions on the activity of protease inhibitor, residual activity of protease inhibitor was analyzed after incubation with $10 \mathrm{mmol}$ concentration of metal ions at $37^{\circ} \mathrm{C}$ for $30 \mathrm{~min}$, Values are presented as mean $\pm \mathrm{SD}$ of three sets of observations

\section{Effect of chemical modifiers}

Chemical modifiers were utilized to carry out modifications of amino acid residues and the subsequent effect of amino acid modifications on protease inhibitor activity was monitored. Both PMSF and Diethyl pyrocarbonate at a higher concentration of $25 \mathrm{mmol}$ was observed to reduce the anti-tryptic activity of protease inhibitor to $19 \%$ and
$14 \%$ respectively leading to inactivation of inhibitor protein. Thus histidine modification by diethyl pyrocarbonate and serine modification by PMSF results in loss of protease inhibitor activity at higher concentrations of these chemical modifiers. A kunitz type serine protease inhibitor form $P$. dubium was inactive by modification of lysine and serine with tri-nitrobenzene-sulfonic acid and 1, 2-cyclohexanedione respectively [30]. 


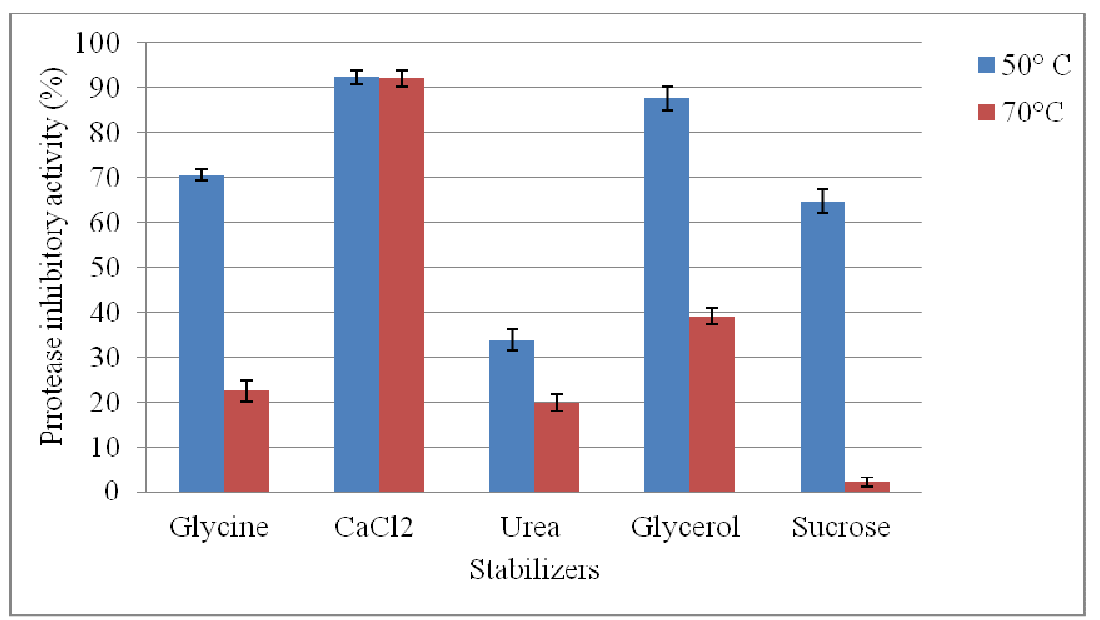

Fig. 10: Effect of thermo stabilizers [glycine (1 M), $\mathrm{CaCl}_{2}(10 \mathrm{mmol})$, glycerol $(10 \%)$, urea $(10 \mathrm{mmol})$, sucrose $(1 \%)$ ] on protease inhibitor activity at $50^{\circ} \mathrm{C}$ and $70^{\circ} \mathrm{C}$, Protease inhibitor was incubated with stabilizers for $3 \mathrm{~h}$ and accessed for residual inhibitor activity

Table 2: Effect of chemical modifications of amino acid residues in the protease inhibitor molecule on the protease inhibition activity

\begin{tabular}{llll}
\hline S. No. & Concentration tested (mM) & Diethyl pyrocarbonate on histidine (DEPC) & PMSF on serine \\
\hline 1 & 0 & 100 & 100 \\
2 & 5 & 90.15 & 91.44 \\
3 & 10 & 86.45 & 85.52 \\
4 & 15 & 52.66 & 81.83 \\
5 & 20 & 42.52 & 51.46 \\
6 & 25 & 19.46 & 14.38 \\
\hline
\end{tabular}

The activity of protease inhibitor expressed as percent residual activity

\section{Stoichiometry of protease-protease inhibitor interaction}

Protease-protease inhibitor interaction was studied and the data is presented in fig. 11. $100 \%$ inhibition of protease corresponding to zero protease activity was observed at $432 \mu \mathrm{g}$ inhibitor.
Thus the stoichiometry of trysin-protease inhibitor interaction is $1: 2$ where $432 \mu \mathrm{g}$ of protease inhibitor is necessary for complete inactivation of $1 \mathrm{mg} / \mathrm{ml}$ of trypsin. The amount of inhibitor required for causing $50 \%$ inhibition (IC-50) of trypsin is $216 \mu \mathrm{g}$.

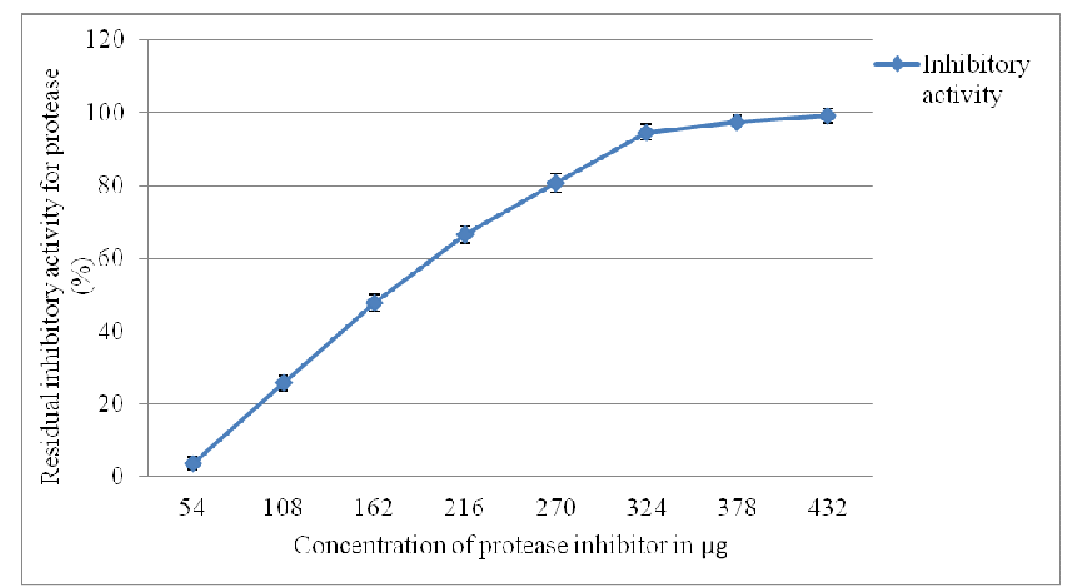

Fig. 11: Stoichiometry of protease-protease inhibitor interaction with preincubation of trypsin along with variable concentrations of inhibitor at $37^{\circ} \mathrm{C}$ for $60 \mathrm{~min}$ followed by analysis of the residual activity of trypsin. The data were presented as mean $\pm S D$

\section{Antimicrobial activity of protease inhibitor}

Antimicrobial assay of purified inhibitor was carried out against bacterial strains Citrobacter freundii, Aeromonas hydrophilla, and Acinetobacter baumannii. The bactericidal effect was analyzed by measuring the zone of diameter observed as a result of the anti proteolytic action of the inhibitor against test organisms.
Inhibition of growth was observed for Citrobacter freundii Aeromonas hydrophilla and Acinetobacter baumani where the was corresponding zone of inhibition was $2.3 \mathrm{~mm}, 1.9 \mathrm{~mm}$ and $1.8 \mathrm{~mm}$ respectively. Protease inhibitors from kunitz family exhibited potential antimicrobial activity against Gram positive and Gramnegative bacteria as Staphylococcus aureus, Salmonella typhimurium, and Escherichia coli [31]. 
Table 3: Antibacterial activity of $P$. vulgaris protease inhibitor

\begin{tabular}{lll}
\hline CC accession number & Name of the organism & Diameter of the zone of inhibition (cm) \\
\hline MCC-2052 & Aeromonas hydrophilla & 1.9 \\
MCC-2078 & Citrobacter freundii & 2.3 \\
MCC-2076 & Acitenobacter baumanii & 1.8 \\
\hline
\end{tabular}

Values are given as mean \pm standard deviation $(n=3)$, screening of antimicrobial property of the P. vulgaris protease inhibitor using well diffusion method on Muller Hinton agar plates. All values are expressed as mean \pm SD of three independent experiments

\section{CONCLUSION}

Phaseolus vulgaris is a source of bioactive components with antihyperglycemic activity. The application of anti proteolytic action of inhibitor is denoted in the current study. The inhibitor was analyzed for different biochemical characteristics as $\mathrm{pH}$ and temperature stability, the effect of metal ions, oxidizing and reducing agents, chemicals modifiers, detergents, stabilizers and IC-50 value. The observations indicated industrial and therapeutic applications protease inhibitor due to its antimicrobial potential. Thus Phaseolus vulgaris is an effective source of protease inhibitor with promising applications in biotechnology similar to Solanum tuberosum that has the highest percentage of protease inhibitor activity [32].

\section{ACKNOWLEDGEMENT}

The authors are thankful to Dr. D. Y. Patil Vidyapeeth, Dr. D. Y. Patil Biotechnology and Bioinformatics Institute, Pune for financial assistance.

\section{AUTHOR CONTRIBUTION}

All authors have equal contributions for carrying out the experimental work as well as preparation of the whole manuscript.

\section{CONFLICT OF INTERESTS}

\section{Declared none}

\section{REFERENCES}

1. Joanitti GA, Freitas SM, Silva LP. Proteinaceous protease inhibitors: structural features and multiple functional faces. Curr Enzyme Inhib 2006;2:199-17.

2. Valueva TA, Mosolov VV. Proteinase inhibitors and their functions in plants: a review. Prikl Biokhim Mikrobiol 2005;41:261-82.

3. Lawrence PK, Koundal KR. Plant protease inhibitors in control of polyphagous insects. Electron J Biotechnol 2002;1:93-9.

4. Ivanov D, Emonet C, Foata F, Affolter M, Delly M, Fisseha M, et al. A serpin from the gut bacterium Bifidobacterium longum inhibits eukaryotic elastase like serine proteases. J Biol Chem 2006;281:17246-52.

5. Mello GC, Oliva MLV, Sumikava IT, Machado OLT, Marangoni S, Matos DGG. Purification and characterization of new trypsin inhibitor from Dimorphanda mollis. J Protein Chem 2000;20:625-32.

6. Lopes AR, Juliano MA, Juliano L, Terra WR. Coevolution of insect trypsins and inhibitors. Arch Insect Biochem Physiol 2004;55:140-52.

7. Gettins P. Serpin structure, mechanism, and function. Chem Rev 2002;102:4751-803.

8. Silverman GA, Bird PI, Carrell RW, Church FC, Coughlin PB, Gettins PG, et al. The sepins are an expanding superfamily of structurally similar but functionally diverse proteins, evolution, mechanism of evolution, novel functions, and revised nomenclature. J Biol Chem 2001;276:33293-6.

9. Lund BM, Baird-Parker TC, Gould GW, Gaithersburg. editors. The production of microbiologically safe and stable foods. The microbiological safety and quality of food. Aspen Publishers; 2003. p. 3-18.

10. Reppond KD, Babbitt JK. Protease inhibitors affect physical properties of arrow tooth flounder and walleye Pollack surimi. J Food Sci 1993;58:96-8.

11. Singh RR, Rao AG. Reductive unfolding and oxidative refolding of a Bowman-Birk inhibitor from horse gram seeds (Doritos biflorus): Evidence for 'hyperreactive' disulfide bonds and ratelimiting nature of disulfide isomerization in folding. Biochem Biophys Acta 2002;1597:280-91.

12. Meriem B, Marie-Claire G, Cindy D, Pierre-Lue C, Dominique M. Hybrid protease inhibitors for pest and pathogen control-a functional cost for the fusion partners? Plant Physiol Bioch 2008;46:701-8.

13. Johnson S, Pellecchia M. Molecular-structure-and fragment based approaches to protease inhibition. Curr Top Med Chem 2006;6:317-29.

14. Kunitz. Crystalline soyabean trypsin inhibitor III. General properties. J Gen Physiol 1947;30:291-310.

15. Englard, Seifter. Precipitation techniques. Methods enzymol Academic Press; 1990. p. 285-300.

16. Lowry $\mathrm{OH}$, Rosebrough NJ, Farr AL, Randall RJ. Protein measurement with the folin phenol reagent. J Biol Chem 1951;193:265-75.

17. Rossomando EF. Ion-exchange chromatography. Methods enzymol Academic Press; 1990.

18. Murray PR, Baron EJ, Pfaller MA, Tenover FC, Yolken HR. Manual of clinical microbiology. 6th ed. ASM Press; Washington DC; 1995. p. 15-8.

19. Olurinola PF. A laboratory manual of pharmaceutical microbiology. Idu Abuja; Nigeria 1996. p. 69-105.

20. Mello GC, Oliva MLV, Sumikava IT, Machado OLT, Marangoni S, Matos DGG. Purification and characterization of new trypsin inhibitor from Dimorphanda mollis. J Protein Chem 2000;20:625-32.

21. Bijina B. Isolation purification and characterization of protease inhibitor from Moringa oleifera. Ph. D. thesis. University of Science and Technology, Cochin; 2006.

22. Bein K, Simons M. Thrombospondin type 1 repeats interact with matrix metalloproteinase 2 Regulation of metalloproteinase activity. J Biol Chem 2000;275:32167-73.

23. Pandhare J, Zog K, Deshpande V. Differential stabilities of alkaline protease inhibitors from actinomycetes: effect of various additives on thermostability. Bioresour Technol 2002;84:165-9.

24. Hamato N, Koshiba T, Pham TN, Tatsumi Y, Nakamura D, Takano $\mathrm{R}$, et al. Trypsin and elastase inhibitors from bitter gourd (Momordica charantia Linn.) seeds: purification, amino acid sequences, and inhibitory activities of four new inhibitors. J Biochem 1995;117:432-7.

25. Jinitha V, Archana G. Purification and characterization of trypsin inhibitor protein from seeds of Momordica Dioica. Asian J Pharm Clin Res 2016;9:335-9.

26. Johnson D, Travis J. The oxidative inactivation of human alpha1-proteinase inhibitor. Further evidence for methionine at the reactive center. J Biol Chem 1979;254:4022-6.

27. Jack CR Jr, Garwood M, Wengenack TM, Borowski B, Curran GL, Lin J. In vivo visualization of Alzheimer's amyloid plaques by magnetic resonance imaging in transgenic mice without a contrast agent. Magn Reson Med 2004;52:1263-71.

28. Bijina B, Sreeja C, Soorej MB, Elyas KK, Bahkali AH, Chandrasekaran M. Protease inhibitor from Moringa oleifera leaves Isolation, purification and characterisation. Proc Biochem 2011;46:2291-300.

29. Jamal S, Poddar NK, Singh LR, Dar TA, Rishi V, Ahmad F. Relationship between functional activity and protein stability in the presence of all classes of stabilizing osmolytes. FEBS J 2009;276:6024-32.

30. Macedo MLR, Viviane AG, Maria DG, Machado FJ, Camillo N, Sérgio M. Trypsin Inhibitor from Poecilanthe parviflora Seeds: 
purification, characterization, and activity against pest proteases. Protein J 2004;23:343-50.

31. Lima TB, Silva ON, Migliolo L, Souza-Filho CR, Gonçalves EG, Vasconcelos IM, et al. A kunitz proteinase inhibitor from corms of Xanthosoma blandum with bactericidal activity. J Nat Prod 2011;74:969-75.

32. Vinyas M, Vijay kumar R, Banappa SU. Evaluation of phenol content, antioxidant, and proteinase inhibitory activity of plant derived protease inhibitors of eight anti-diabetic plants. Asian J Pharm Clin Res 2016;9:215-9.

\section{How to cite this article}

- $\quad$ Ashwini Puntambekar ${ }^{1}$, Manjusha Dake. Protease inhibitor from white cranberry beans (Phaseolus vulgaris) isolation, purification and characterization. Int J Pharm Pharm Sci 2017;9(9):190-198. 